\title{
„Anafora”, czyli o celowości działań
}

\section{„Anafora. Časopis za znanost o književnosti” r. I, nr 1, 2014, 164 s.}

W styczniu bieżącego roku ukazał się pierwszy numer czasopisma literaturoznawczego „Anafora”, utworzonego w Katedrze Literatury Chorwackiej Wydziału Filozoficznego Uniwersytetu w Osijeku. Funkcję redaktora naczelnego pełni prof. dr. sc. Ružica Pšihistal. W składzie redakcji, obok badaczy afiliowanych w Chorwacji, znajdują się prof. dr. sc. Stjepan Blažetin (Pecs) oraz prof. UAM dr hab. Krystyna Pieniążek-Marković (Poznań). Radę naukową tworzy międzynarodowe gremium, reprezentujące ośrodki badawczo-dydaktyczne z Osijeku, Zagrzebia, Splitu, Đakova, Tuzli, Szegedu, Pecsu i Poznania. Periodyk został zaprojektowany jako półrocznik. Jednocześnie z wersją papierową (pierwotną, nakład 150 egzemplarzy) ukazuje się także elektroniczna, dostępna na portalu Hrčak, adres URL < http:// hrcak.srce.hr/anafora>. Struktura publikacji obejmuje kolejno: artykuły, recenzje, informacje dla autorów oraz adresy autorów.

Zgodnie z intencją wydawcy na łamach „Anafory” ukazywać się będą prace poświęcone zarówno badaniom literackim, jak i obejmujące wyniki eksploracji naukowych zorientowanych na bliskie filologii dyscypliny humanistyczne i społeczne. Podstawowym językiem publikacji jest język chorwacki, ale od drugiego numeru włączane będą także również napisane po angielsku, węgiersku i polsku. Każdy artykuł poddawany jest double-blind review process. O dopuszczeniu do druku decyduje jednoznacznie pozytywne zaopiniowanie tekstu przez dwóch recenzentów, którzy dokonują także jego klasyfikacji w ramach podziału: artykuł naukowy źródłowy, artykuł naukowy przeglądowy, artykuł sprawozdawczy.

Lektura liczącego 164 strony, inaugurującego tomu, który należy traktować jako wizytówkę wydawcy, wskazówkę dla potencjalnych autorów oraz 
egzemplum dla kolejnych numerów, skłania do pozytywnych wniosków. Pod względem merytorycznym poprzeczka ustawiona jest bardzo wysoko. Główną część publikacji stanowi sześć artykułów, silnie zakotwiczonych w europejskim dyskursie literaturoznawczym. Każdy z nich zorientowany jest na odmienny materiał źródłowy, analizowany w różnych optykach badawczych. Tworzą one jednak całość, formując swoisty przekrój przez aktualnie najważniejsze pola badawcze.

Prezentowany numer otwiera praca Beáty Thomki, poświęcona problematyce postaci w badaniach narratologicznych, pt. Pojam lika u naratologiji (Postać w narratologii). Wychodząc od ustaleń Władimira Proppa, dotyczących struktury formalnej jako elementu, który każdorazowo generuje sensy tj. treść fabularną, autorka opiera analizę na problemach poetyki, estetyki i stylu Michaiła Bachtina oraz poetyki i tożsamości narracyjnej Paula Ricoeura. Bazując na ich rozważaniach, dotyczących konstrukcji postaci fikcyjnych oraz możliwości rozwoju samorozumienia, kreśli krótką interpretację dwóch opowiadań: Prostoty serca Gustawa Flauberta oraz Śmierci w Wenecji Tomasza Manna.

Po pracy teoretycznoliterackiej, skoncentrowanej na źródłach wpisanych w kanon literatury powszechnej, czytelnik otrzymuje równie mocno opartą na fundamentach teoretycznych, a jednocześnie niezwykle ciekawą i trafną analitycznie propozycję nowego odczytania języka tradycyjnych śpiewów z Međimurja. Lidija Bajuk, w artykule Hrvatski tradicijski napjevi Međimurja na tragu Havelockovih kognitivnolingvistickkih koncepata (Chorwackie śpiewy z Međimurja w optyce kognitywno-lingwistycznych teorii Erica Havelocka), przedstawia autorski podział tytułowych utworów, którego podstawą są dwa kluczowe kognitywno-lingwistyczne założenia badawcze twórcy. Do pierwszej grupy zalicza śpiewy wpisane w przekaz ustny, który współodczuwa zachowanie istot mitycznych oraz ludzi, znajdujących się w mitycznym lub rzeczywistym środowisku kulturowym. Na drugi typ składają się utwory podporządkowane językowi przekazu pisanego, który artykułuje ,ja". Zgodnie z determinantami lingwistyki kognitywnej, badaczka analizuje wymienione dzieła w kontekście dwukierunkowej twórczej współpracy światopoglądu autora/wykonawcy i słuchacza, których opinie prowadzą do reinterpretacji i redefinicji świata.

Pozostając w kręgu interpretacji narracyjnych, Krešimir Šimić w tekście Eros u Vetranovićevoj „Istoriji od Dijane” (Eros w „Historii Diany” Mavra 
Vetranovicia) poświęca uwagę badawczą jednej z końcowych scen dramatu, której schemat fabularny obejmuje interwencję Merkurego i uwolnienie Kupidyna. W mediacji posłańca bogów między Dianą a synem Marsa, literaturoznawca z Osijeku lokuje prokreacyjną funkcjonalizację Erosa. Jego scholastyczną eksplikację określa mianem wyróżnika dzieł Vetranovicia na tle zarówno chorwackiej, jak i europejskiej literatury pastoralnej.

Chorwacki materiał źródłowy czyni podstawą swych analiz także Dubravka Brunčić (Postmodernističke parodijske strategije u romanu „Epitaf carskog gurmana” Veljka Barbierija; Postmodernistyczne strategie parodystyczne w powieści „Epitafium cesarskiego smakosza” Veljka Barbieriego), pokazując nieszablonowe zastosowanie teorii parodii (jako mikropraktyki) Lindy Hutcheon. Wychodząc od postmodernistycznego paradygmatu stylistyczno-poetyckiego, autorka rozważa parodystyczne i subwersywne strategie dzieła, takie jak: parodiowanie dziennika jako gatunku autobiograficznego, problematyzowanie użyteczności przekazów historiograficznych oraz interpolowanie gastronomicznych gatunków subliterackich. Jednocześnie traktuje je jako media, poprzez które manifestuje się ambiwalentna polityka przekazu postmodernistycznego.

Odejście od stricte literaturoznawczej orientacji badawczej, obecne już w tekście Lidiji Bajuk, znajduje swe potwierdzenie w pracy Milicy Lukić i Very Blažević Krezić Bašćanska ploča kao književno nadahnuće i instrument lingvoslitističke analize (Płyta $\mathrm{z}$ Baški jako inspiracja literacka $\mathrm{i}$ instrument analizy lingwistyczno-stylistycznej), w której autorki z powodzeniem wykorzystują metody i narzędzia stylistyki, od poziomu grafetycznego i grafemicznego, do syntaktycznego. W wierszach składających się na tomik poezji Baščanska ploča - poema (Płyta z Baški - poemat) Mila Pešordy, badaczki analizują ,poziom wrażliwości pióra autora” w odniesieniu do najstarszego okresu w historii chorwackiego języka i literatury. Wskazują i opisują związki intertekstualne analizowanych utworów z pomnikami, które ukształtowały chorwacką literaturę średniowieczną. Ważną częścią artykułu jest appendix, zawierający wyniki porównawczej numerologicznej analizy Płyty z Baški i zbioru poezji Mila Pešordy.

Klamrą spajającą artykuły, składające się na omawianą publikację, jest tekst Ružicy Pšihistal, w którym czytelnik wraca do teoretyczno-literackich rozważań, rozpoczętych w pracy inaugurującej numer. W Uvod u alegoriju: aliud verbis, aliud sensu (Wprowadzenie do alegorii: aliud verbis, 
aliud sensu) badaczka, w pierwszej kolejności, podejmuje kwestię współtworzenia historii alegorii przez różne i często odmienne humanistyczne paradygmaty naukowe. Następnie, na potrzeby heurystycznych rozważań, nazywa i omawia trzy główne pola eksploracyjne alegorii: jej retoryczno-stylistyczną fakturę, receptywny proces czytania/tłumaczenia oraz alegorię jako rodzaj literacki. Tak nakreślone rozważania umożliwiają jej analizę tropologicznej, hermeneutycznej i historycznoliterackiej zawartości alegorii i dalsze rozszerzanie pola badawczego.

Dobór recenzowanych publikacji uzupełnia przekrojową koncepcję problemową numeru oraz wskazuje dalszy kierunek zakładanej drogi wydawniczej, tj. otwarcie na teksty, dla których materią źródłową są nie tylko literatura i język chorwacki. Dział lektur, liczący pięć recenzji, inauguruje opinia merytoryczna Sanji Jukić, dotycząca reedycji wydanego w 2007 roku przez Wydawnictwo Naukowe UAM tomu zbiorowego Nasza środkowoeuropejska ars combinatoria (red. Krystyna Pieniążek-Marković, Goran Rem, Bogusław Zieliński, 540 s.). Reedycja (red. Krystyna Pieniążek-Marković, Goran Rem, Bogusław Zieliński, wydawca: Wydział Filozoficzny Uniwersytetu w Osijeku, współwydawcy: Chorwackie Towarzystwo Literackie Oddział Slawońsko-Barańsko-Srijemski oraz Uniwersytet im. Adama Mickiewicza w Poznaniu, 2012), poświęcona zmarłemu w 2010 roku Aleksandrowi Flakerowi, została rozszerzona o jego recenzję zbioru Widzieć Chorwacje. Panorama literatury i kultury chorwackiej 1990-2005 (red. Krystyna Pieniążek-Marković, Goran Rem, Bogusław Zieliński, Wydawnictwo Naukowe UAM, Poznań 2005, 722 s.) pt. Slamnig živi u Osijeku i Poznanju (Slamnig żyje w Osijeku i Poznaniu) oraz o artykuł Gorana Rema poświęcony pracom naukowym i literackim urodzonego w Białymstoku badaczowi. Instytut Filologii Słowiańskiej UAM jest także obecny w omówieniu, autorstwa Jeleny Lachner, trzeciego numeru „Poznańskich Studiów Slawistycznych" zatytułowanego Zaklęcie, zamówienie, zażegnanie. Magiczna moc słów w folklorze słowiańskim (redaktorzy tematyczni Michał Buchowski, Joanna Rękas, Wydawnictwo Naukowe UAM, 2013, 316 s.).

Na uwagę zasługuje niezwykle szczegółowa, merytoryczna ocena monografii Cvijety Pavlović Uvod u klasicizam (Wprowadzenie do klasycyzmu, wyd. Leykam International, Zagrzeb 2012, 310 s.). Perina Meić kreśli w niej sproblematyzowane historyczno-literackie résumé o silnym ugruntowaniu komparatystycznym. Ważne miejsce zajmuje także recenzja Mateja Čepla, 
poświęcona XIV tomowi historii literatury chorwackiej w ujęciu komparatystycznym (Komparativna povijest hrvatske književnosti. Zbornik radova XIV. Romantizam - ilirizam - preporod, red. Cvijeta Pavlović, Vinka Glunčić-Bužančić, Andrea Meyer-Fraatz, wyd. Književni krug i Katedra Literatury Porównawczej Wydziału Filozoficznego Uniwersytetu w Zagrzebiu, Split-Zagrzeb 2012, 363 s.). Dział recenzji, podobnie jak artykułów, zamyka tekst redaktor naczelnej, będący interpretacyjnym omówieniem publikacji Rječnik stilskih figura Krešimira Bagicia (Słownik figur stylistycznych, wyd. Školska knjiga, Zagrzeb 2012, 356 s.).

Poza niewątpliwymi walorami merytorycznymi, aktualnością podejmowanych tematów oraz jasnym podziałem prac, pomimo odmienności tematycznej, pierwszy numer „Anafory” cieszy oko nieprzeciętną szatą graficzną i techniczną pedanterią. Założona przez redaktorów szeroka perspektywa humanistyczna z pewnością pomoże w zdobywaniu coraz szerszego grona czytelników i autorów, a co za tym idzie, uznania na arenie międzynarodowych czasopism naukowych. 